\title{
Risk of chlorine dioxide as emerging contaminant during SARS-CoV-2 pandemic: enzyme, cardiac, and behavior effects on amphibian tadpoles
}

\author{
Paola M. Peltzer ${ }^{1,2} \cdot$ Ana P. Cuzziol Boccioni $i^{1,2}$. Andrés M. Attademo ${ }^{1,2} \cdot$ Candela S. Martinuzzi $^{1,2}$. \\ Carlina L. Colussi ${ }^{1} \cdot$ Rafael C. Lajmanovich ${ }^{1,2}$
}

Accepted: 21 October 2021 / Published online: 3 November 2021

(c) The Author(s), under exclusive licence to Korean Society of Environmental Risk Assessment and Health Science 2021

\begin{abstract}
Objective The use of chlorine dioxide $\left(\mathrm{ClO}_{2}\right)$ increased in the last year to prevent SARS-CoV-2 infection due to its use as disinfectant and therapeutic human treatments against viral infections. The absence of toxicological studies and sanitary regulation of this contaminant represents a serious threat to human and environmental health worldwide. The aim of this study was to evaluate the acute toxicity and sublethal effects of $\mathrm{ClO}_{2}$ on tadpoles of Trachycephalus typhonius, which is a common bioindicator species of contamination from aquatic ecosystems.

Materials and methods Median lethal concentration (LC50), the lowest-observed effect concentration (LOEC), and the noobserved effect concentration (NOEC) were performed. Acetylcholinesterase (AChE) and glutathione-S-transferase (GST) activities, swimming behavior parameters, and cardiac rhythm were estimated on tadpoles of concentrations $\leq$ LOEC exposed at 24 and $96 \mathrm{~h}$. ANOVA and Dunnett's post-hoc comparisons were performed to define treatments significance $(p \leq 0.05)$. Results The $\mathrm{LC} 50$ of $\mathrm{ClO}_{2}$ was $4.17 \mathrm{mg} \mathrm{L}^{-1}$ (confidence limits: 3.73-4.66). In addition, NOEC and LOEC values were 1.56 and $3.12 \mathrm{mg} \mathrm{L}^{-1} \mathrm{ClO}_{2}$, respectively, at $48 \mathrm{~h}$. AChE and GST activities, swimming parameters, and heart rates increased in sublethal exposure of $\mathrm{ClO}_{2}\left(0.78-1.56 \mathrm{mg} \mathrm{L}^{-1}\right)$ at $24 \mathrm{~h}$. However, both enzyme activities and swimming parameters decreased, whereas heart rates increased at $96 \mathrm{~h}$.

Conclusion Overall, this study determined that sublethal concentrations of $\mathrm{ClO}_{2}$ produced alterations on antioxidant systems, neurotoxicity reflected on swimming performances, and variations in cardiac rhythm on treated tadpoles. Thus, our findings highlighted the need for urgent monitoring of this chemical in the aquatic ecosystems.
\end{abstract}

Paola M. Peltzer

paolapeltzer@hotmail.com

$\triangle$ Ana P. Cuzziol Boccioni

anapaulacuzziolboccioni@gmail.com

1 Laboratorio de Ecotoxicología, Facultad de Bioquímica y Ciencias Biológicas, Universidad Nacional del Litoral, Santa Fe, Argentina

2 Consejo Nacional de Investigaciones Científicas y Técnicas (CONICET), Buenos Aires, Argentina 


\section{Graphical abstract}
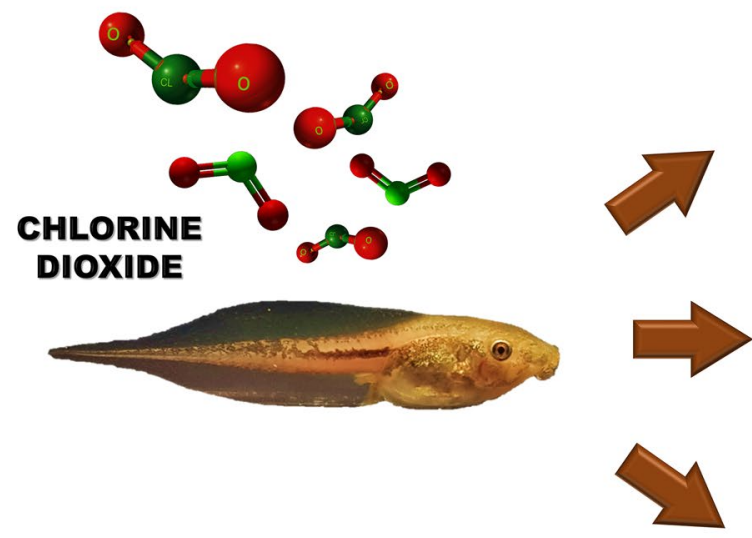

\section{Cardiac function}
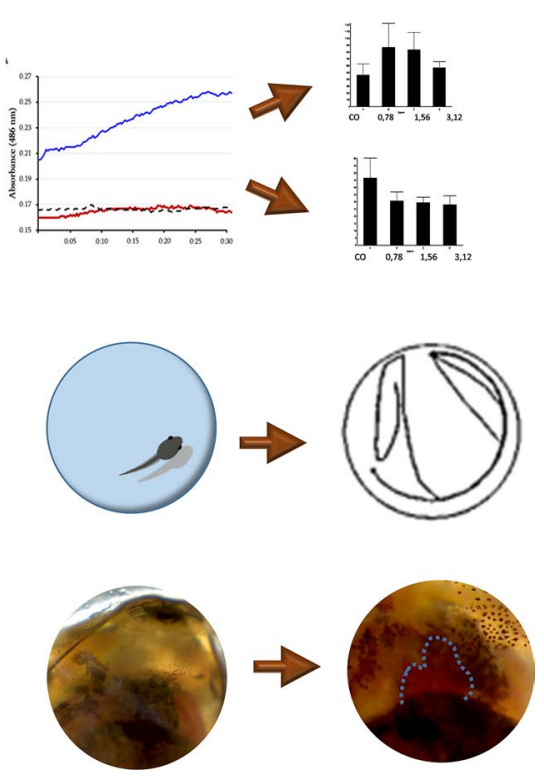

Keywords Chlorine disinfectant COVID-19 treatment $\cdot$ Anurans $\cdot$ Sublethal toxicity

\section{Introduction}

Chlorine dioxide $\left(\mathrm{ClO}_{2}\right)$ is a disinfection agent that is massively used due to its high oxidizing capacity that deactivates chlorine-resistant pathogens and prevents biofilm formation [1]. In the last decades, drinking water treatments and industrial processes increase the use of $\mathrm{ClO}_{2}$, which replaces other chlorine disinfectants $[2,3]$. Several studies determined that the consumption of $\mathrm{ClO}_{2}$ solutions is a preventive and therapy tool against different viral human infections, such as HIV/AIDS $[4,5]$. The occurrence of $\mathrm{ClO}_{2}$ had an exponential increase in surface water during the last two years due to its use as treatment and preventive therapy against SARS-CoV-2 [6, 7]. Although $\mathrm{ClO}_{2}$ lacks of scientific and sanitary approval as medical treatment against SARS-CoV-2 for human consumption, the $\mathrm{ClO}_{2}$ began to be commonly commercialized specially in Latin America [8-10]. Moreover, the increased use of $\mathrm{ClO}_{2}$, together with other pharmaceutical products and disinfection agents poses a serious threat to aquatic systems, animal and human health $[11,12]$.

In addition, treatment protocols to prevent waterborne pathogens in public water systems and drinking water was determined by the World Health Organization, including also those treatments with $\mathrm{ClO}_{2}$ water. It has been reported that a concentration higher than $0.5 \mathrm{mg} \mathrm{L}^{-1}$ of free chlorine and $2.19 \mathrm{mg} \mathrm{L}^{-1} \mathrm{ClO}_{2}$ inactivate SARS viruses. In general, residual chlorine and $\mathrm{ClO}_{2}$ concentrations in wastewater treatments do not exceed $6.5 \mathrm{mg} \mathrm{L}^{-1}$ and $10 \mathrm{mg}$ $\mathrm{L}^{-1}$, respectively $[6,13,14]$. However, solutions of $20 \mathrm{mg}$
$\mathrm{L}^{-1} \mathrm{ClO}_{2}$ are recommended for SARS-CoV-2 inactivation for domestic use as disinfectant, whereas solutions over $500 \mathrm{mg} \mathrm{L}^{-1} \mathrm{ClO}_{2}$ are suggested for hospital and health unit care disinfections. Thus, maximum concentrations of $0.8 \mathrm{mg} \mathrm{L}^{-1} \mathrm{ClO}_{2}$ and $1.0 \mathrm{mg} \mathrm{L}^{-1}$ chlorite ion for drinking waters were recommended by U.S.EPA recommends [15].

During COVID-19 pandemic, sanitation with chlorinated products increased in domestic wastewater, drinking water, and surface water, which pose a healthy human and environmental risk [16]. For example, concentrations of chlorine ranged between 1.5 and $4-5 \mathrm{mg} \mathrm{L}^{-1}$ in wastewater treatment plants were used for preventive measure in China [17]. The same study recorded residual chlorine concentration up to $0.4 \mathrm{mg} \mathrm{L}^{-1}$ in some Chinese lakes, where had not been detected before the actual COVID pandemic. This concentration produced acute toxicity on freshwater organism [17].

The effect of $\mathrm{ClO}_{2}$ on virus, bacteria, algae, and plankton has been analyzed during last decades [18-20]. However, few studies described $\mathrm{ClO}_{2}$ effect on wild organisms, such as aquatic vertebrates. The $\mathrm{ClO}_{2}$ lethal toxicity has been reported for the early stages of several fishes [21, 22], chironomid larvae [23], and nematodes [24]. It is important to note that $\mathrm{ClO}_{2}$ toxicity data obtained for common sentinel organisms of model organisms (e.g., Cyprinidae, Daphnidae, Brachionidae, and Hyalelladae) is generally used by U.S.EPA water quality criteria method [25]. The monitoring of $\mathrm{ClO}_{2}$ on aquatic environments and ecotoxicological studies that include lethally and sublethal parameters of other 
sentinel species is needed. To the best of our knowledge, no information exists on $\mathrm{ClO}_{2}$ toxicity on amphibian tadpoles.

Amphibians present the highest decrease of population than other vertebrates worldwide, due to their complex life cycle that involves physiological, morphological, and behavioral changes during metamorphosis. These biological traits increase amphibian vulnerability to man-made environmental modifications [26-28]. Contaminants (e.g., pharmaceuticals, agrochemicals, health care products) affect survival and produce several sublethal effects on amphibians [29, 30]. Death and sublethal effects at different biological levels (e.g., cell, endocrinology, metabolic and behavior alterations, metamorphosis rates, malformations, among others) were determined for amphibian tadpoles [31-33]. In addition, the cholinesterase (ChEs) enzyme activity is useful to indicate the presence of neurotoxic substances in amphibian tadpoles [34]. Moreover, acetylcholinesterase (AChE) activity is inhibited in presence of neurotoxic substances, leading to acetylcholine accumulation and producing alterations in nerve function that can be lethal on exposed organisms [35]. The alteration in normal AChE activity has been linked with neurotoxic effects on locomotor activity in different invertebrates and vertebrates $[36,37]$. Thus, glutathione-Stransferase (GST) activity is used to assess the detoxification process of contaminants [38]. The GST activity is frequently quantified in amphibian tadpoles exposed to several contaminants, such as pharmaceutical residues [39, 40]. However, other sublethal effects of tadpole regarding to physiology, such as heart function and rhythm are poorly explored [41]. Tadpoles' heart rate is considered novel biomarkers in amphibian ecotoxicology $[32,42]$ and could reflect of what happens at biochemical, physiological, and ecological levels in aquatic organisms exposed to different contaminants [43].

The aim of this study was to evaluate the acute and sublethal effects of $\mathrm{ClO}_{2}$ on Trachycephalus typhonius tadpoles. It has been hypothesized that the $\mathrm{ClO}_{2}$ produces different biological changes on AChE and GST activities and physiological (cardiac rhythm and swimming behavior) endpoints.

\section{Results and discussion}

\section{Mortality}

$\mathrm{LC}_{50}$ of $\mathrm{ClO}_{2}$ was $4.17 \mathrm{mg} \mathrm{L}^{-1}$ (CL: 3.73-4.66) at $48 \mathrm{~h}$. NOEC and LOEC values were 1.56 and $3.12 \mathrm{mg} \mathrm{L}^{-1} \mathrm{ClO}_{2}$, respectively, at $48 \mathrm{~h}$. The $\mathrm{TU}$ for $\mathrm{ClO}_{2}$ was 23.98 , meaning a high acute toxicity substance (Class IV) in the hazard classification system.

The toxicity of $\mathrm{ClO}_{2}$ has been studied in alkaline solutions when it becomes chlorate [44]. In fishes (feather minnows Pimephales promelas), the $\mathrm{LC}_{50}$ was determined to be $0.19 \mathrm{mg} \mathrm{L}^{-1}$ of $\mathrm{ClO}_{2}$, whereas $\mathrm{LC}_{50}$ was recorded to
$63.38 \mathrm{mg} \mathrm{L}^{-1}$ of chlorite within $24 \mathrm{~h}$ of exposure $[45,46]$. In amphibians, the $\mathrm{LC}_{50}$ values are only reported for chlorite concentration that varied between $65.69 \mathrm{mg} \mathrm{L}^{-1}$ (Lithobates pipiens) and $149.60 \mathrm{mg} \mathrm{L}^{-1}$ (Anaxyrus americanus). Chlorite is much less toxic than its precursor chlorine [25]. No estimation could be made regarding to the toxicity of $\mathrm{ClO}_{2}$ in terms of values of $\mathrm{LC}_{50}$ obtained in this study for T. thyphonius with respect to other amphibian species because mortality values of $\mathrm{ClO}_{2}$ are unknown for other anurans. Time of exposure, acclimation temperature, and chlorine species can be considered as factors that influence the $\mathrm{ClO}_{2}$ toxicity [46]. For example, the $\mathrm{LC}_{50}$ values of $\mathrm{ClO}_{2}$ varied between 0.41 and $0.23 \mathrm{mg} \mathrm{L}^{-1}$ for different instar larvae (1st to $4 \mathrm{th}$ ) of chironomid species at $24 \mathrm{~h}$ [23], whereas these values were $0.022 \mathrm{mg} \mathrm{L}^{-1}$ for planktonic crustacean (Daphnia magna) and $47 \mathrm{mg} \mathrm{L}^{-1}$ for mosquitoes larvae [25].

\section{Enzyme activities}

AChE activity significantly increased $(51 \%, F=7.18, p<$ $0.01)$ in $0.78 \mathrm{mg} \mathrm{L}^{-1} \mathrm{ClO}_{2}$ treated tadpoles with respect to CO (Dunnett's test $p<0.01$ ) at $24 \mathrm{~h}$ (Fig. 1A, Table S1 in supplementary material). In contrast, AChE activity significantly decreased $(F=5.16, p<0.01)$ between 32.15 and $36.51 \%$ in $\mathrm{ClO}_{2}$ treated tadpoles with respect to $\mathrm{CO}$ (Dunnett's test $p<0.01$ ) after $96 \mathrm{~h}$ of exposure (Fig. 1B, Table S1). In addition, exposure to $\mathrm{ClO}_{2}$ also altered the AChE activity of larvae of indianmeal moth (Plodia interpunctella) [47]. Matsushita et al. [48] who recognized $\mathrm{ClO}_{2}$ as insecticide, reported that $\mathrm{ClO}_{2}$ produced a fast increase of AChE activities in $P$. interpunctella than those insecticidebased-malathion or -methidathion formulations. Moreover, the AChE activities decreased with increasing chlorination time in $\mathrm{ClO}_{2}$ treated T. thyphonius tadpoles at 24 and after $96 \mathrm{~h}$, which may be explained in terms of enzyme synthesis as a response to initial inhibition [49]. It is important to note that $\mathrm{AChE}$ is involved in the cleavage of the acetylcholine neurotransmitter within the synaptic cleft. An inhibition of AChE activity leads to acetylcholine accumulation, hyperstimulation of nicotinic and muscarinic receptors, and disrupted neurotransmission, consequently affecting the animal behavior [50].

The GST activity of $\mathrm{ClO}_{2}$ treated tadpoles significantly increased $(F=4.47, p<0.05)$ in $0.78 \mathrm{mg} \mathrm{L}^{-1}$ and $1.56 \mathrm{mg}$ $\mathrm{L}^{-1}$ concentrations with respect to $\mathrm{CO}$ (Dunnett's test $p<$ $0.05)$ at $24 \mathrm{~h}(87.84 \%$ and $79.41 \%$, respectively; Fig. 1B, Table S1). There was a positive correlation between the responses of both AChE and GST enzyme activities ( $r$ Spearman $=1 ; p<0.01)$ at $24 \mathrm{~h}$. The mean GST activity significantly decreased $(30 \%, F=8.19, p<0.01)$ in $0.78 \mathrm{mg}$ $\mathrm{L}^{-1} \mathrm{ClO}_{2}$ concentration with respect to $\mathrm{CO}$ (Dunnett's test $p<0.01$ ) after $96 \mathrm{~h}$ (Fig. 1B, Table S1). 
Fig. 1 Acetylcholinesterase (AChE) and glutathione-Stransferase (GST) activities (nmol min ${ }^{-1} \mathrm{mg}^{-1}$ protein) in Trachycephalus typhonius tadpoles from control (CO) and chlorine dioxide $\left(\mathrm{ClO}_{2} \mathrm{mg}\right.$ $\mathrm{L}^{-1}$ ) treatments, at $24 \mathrm{~h}$ (left) and $96 \mathrm{~h}$ (right) of exposure. $p<0.05(*)$ and $p<0.01(* *)$ indicates statistical differences with respect to $\mathrm{CO}$
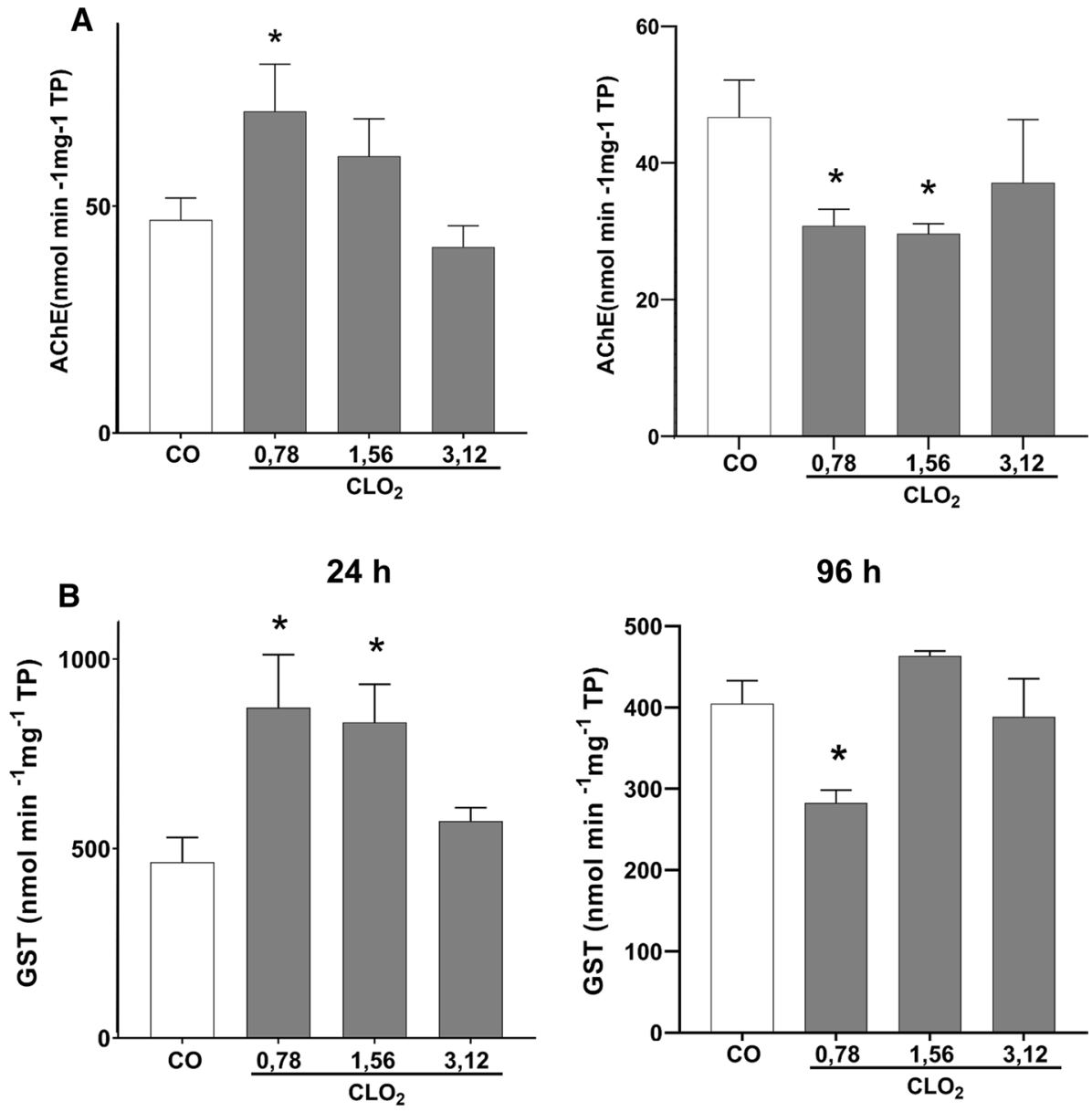

The $\mathrm{ClO}_{2}$ is recognized as a powerful oxidant that affects the first line of antioxidant defense, which is mediated by GST in animals [51]. Besides, the GST plays a pivotal role in cellular detoxification via conjugation of their electrophilic group with the GSH nucleophilic group of harmful contaminants. In contrast to our results, Elia et al. [52] reported an increase in liver GST activity in carp fishes (Cyprinus carpio) exposed to $1.6 \mathrm{mg} \mathrm{L}^{-1} \mathrm{ClO}_{2}$ after 20 days, suggesting that GST acts as a useful biomarker of disinfectants-mediated oxidative stress. The significant decrease in the GST activity in treated tadpoles exposed to $0.76 \mathrm{mg} \mathrm{L}^{-1}$ of $\mathrm{ClO}_{2}$ after $96 \mathrm{~h}$, could be related to the availability of substrate of this enzyme. It is well known that $\mathrm{ClO}_{2}$ oxidizes the glutathione and produces several products that block substrates for normal reaction [53].

\section{Swimming activity}

The mean total distance of $\mathrm{ClO}_{2}$ treated tadpoles significantly increased $(F=39.73 p<0.01)$ in 0.78 and $3.12 \mathrm{mg}$ $\mathrm{L}^{-1} \mathrm{ClO}_{2}$ concentrations $(103.19 \%$ and $139.36 \%$, respectively) with respect to $\mathrm{CO}$ (Dunnett's test $p<0.01$ ) at $24 \mathrm{~h}$ (Fig. 2A, Table S1). The mean speed of $\mathrm{ClO}_{2}$ treated tadpoles increased $(F=77.18, p<0.01)$ in all concentrations $(103.16 ; 78.29$ and $139.36 \%$ for $0.78 ; 1.56$ and $3.12 \mathrm{mg}$ $\mathrm{L}^{-1}$, respectively; Fig. $2 \mathrm{~B}$, Table $\mathrm{S} 1$ ) with respect to $\mathrm{CO}$ (Dunnett's test $p<0.01)$. The global activity significantly increased $(F=53,02, p<0.05)$ at 1.56 and $3.12 \mathrm{mg} \mathrm{L}^{-1} \mathrm{ClO}_{2}$ concentrations (456.57 and 994.48\%, respectively; Fig. 2C, Table S1) with respect to CO (Dunnett's test $p<0.05$ ). The effects of $\mathrm{ClO}_{2}$ concentrations on global activity were negatively correlated with both enzyme activities $(r$ Spearman $=$ $-1 ; p<0.01)$ at $24 \mathrm{~h}$.

The mean total distance significantly decreased $(F=44.03, p<0.05)$ in 1.56 and $3.12 \mathrm{mg} \mathrm{L}^{-1} \mathrm{ClO}_{2}$ treated tadpoles (43.67 and $66.51 \%$, respectively) with respect to CO (Dunnett's test $p<0.05$ ) after $96 \mathrm{~h}$ (Fig. 2A, Table S1). Also, the mean speed significantly decreased $(F=18.04$, $p<0.05)$ in the same concentrations $(44.4$ and $58.34 \%$, respectively) with respect to $\mathrm{CO}$ (Dunnett's test $p<0.05$; Fig. 2B, Table S1)). Similarly, the global activity significantly decreased $(F=25.8, p<0.05)$ in $0.78 \mathrm{mg} \mathrm{L}^{-1} \mathrm{ClO}_{2}$ treated tadpoles $(64.76 \%)$ with respect to $\mathrm{CO}$ (Dunnett's test $p<0.05$ ) after $96 \mathrm{~h}$ (Fig. 2C, Table S1).

The observed responses of swimming activity parameters indicated that $\mathrm{ClO}_{2}$ affects the mechanisms involved 
Fig. 2 Swimming activity of Trachycephalus typhonius tadpoles of control $(\mathrm{CO})$ and chlorine dioxide $\left(\mathrm{ClO}_{2} \mathrm{mg} \mathrm{L}^{-1}\right)$ treatments at $24 \mathrm{~h}$ (left) and after 96 h (right) of exposure: A Total distance moved $(\mathrm{cm}) ; \mathbf{B}$ Mean speed $\left(\mathrm{cm} \mathrm{s}^{-1}\right)$; C Global activity $\left(\mathrm{cm}^{2}\right)$, showing the trajectory of individual in each concentration. $p<0.05(*)$ and $p<0.01(* *)$ indicates statistical differences with respect to $\mathrm{CO}$
$24 \mathrm{~h}$

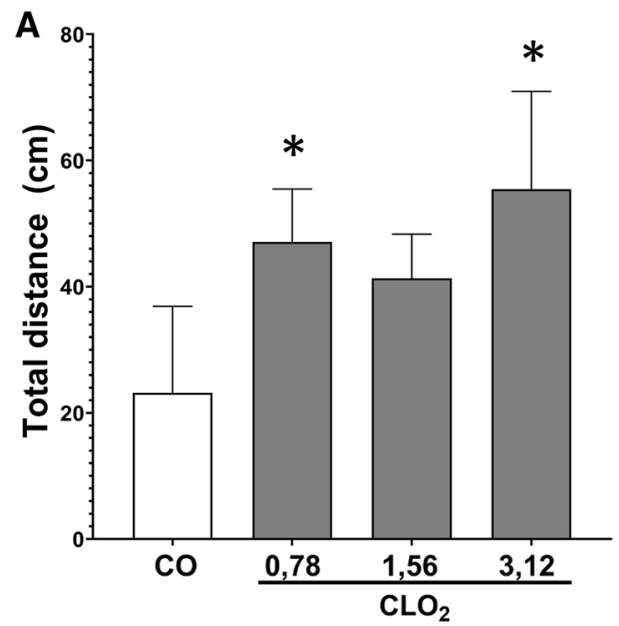

$96 \mathrm{~h}$

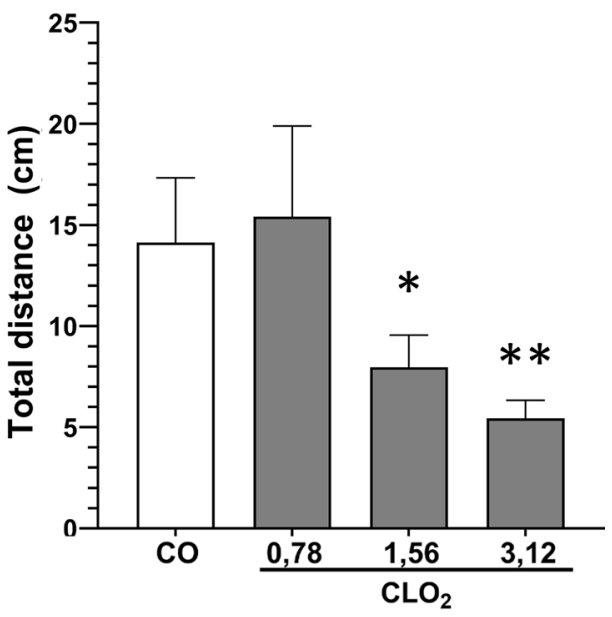

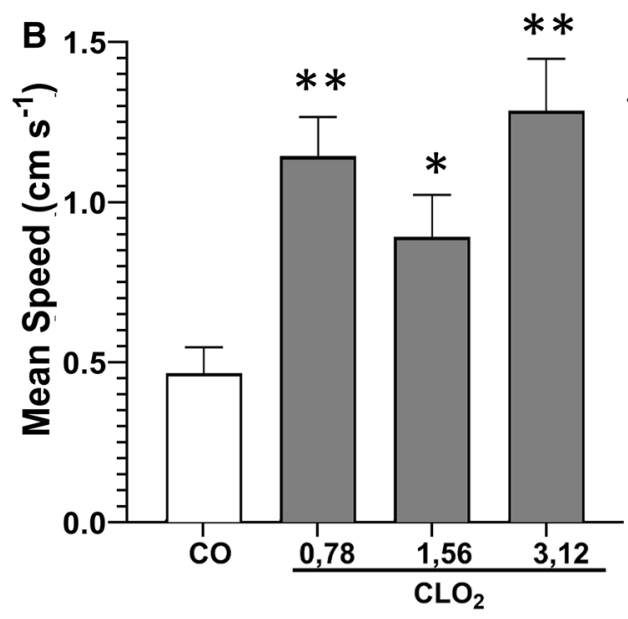
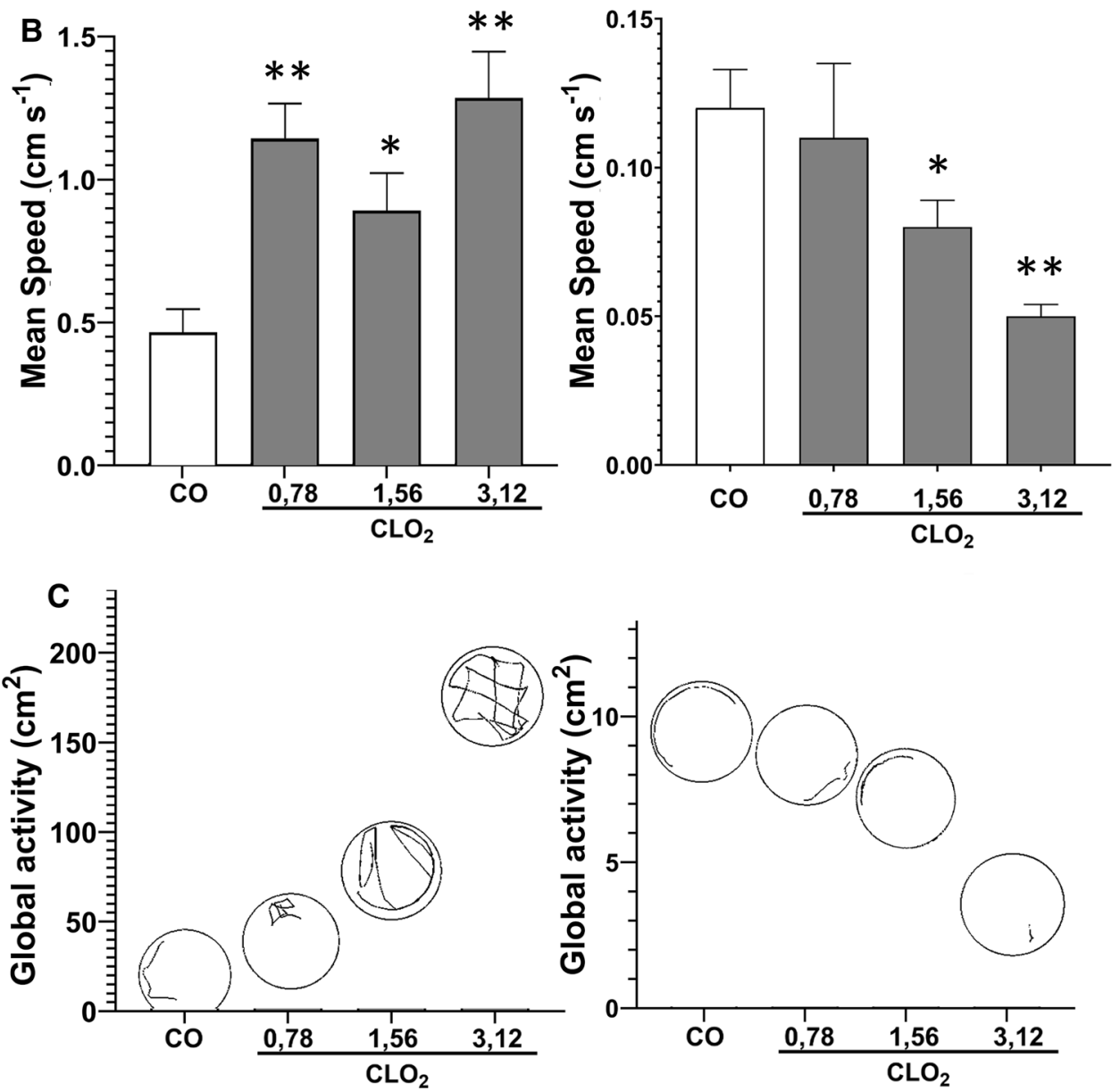

in swimming behavior at different times (24 and after $96 \mathrm{~h}$ ). For example, swimming behavior has been related to AChE activity in invertebrates, fish, and amphibian larvae exposed to different contaminants [32, 34, 39, 54, 55]. In this sense, swimming behavior observed in $\mathrm{ClO}_{2}$ treated tadpoles at $24 \mathrm{~h}$ may be related to neurotoxicity through AChE over-activation [50]. Conversely, decrease in swimming behavior observed in $\mathrm{ClO}_{2}$ treated tadpoles after $96 \mathrm{~h}$ could be related to the disruption of the normal nervous system function by inhibition of the AChE activity and the resulting transduction signal $[56,57]$. Regarding to these behavior disparities, a higher expression of $\mathrm{AChE}$ genes may occur as a response to acetylcholine neurotransmitters accumulation [58]. 
Yonkos et al. [45] described gill pathology with epithelial lifting, hypertrophy, hyperplasia, lamellar fusion, and necrosis on feather minnow $P$. promelas exposed to $\mathrm{ClO}_{2}$. Histological alterations in gills may produce alteration in swimming activity due to its demands of oxygen [59]. In this sense, the decrease of swimming parameters after $96 \mathrm{~h}$ of exposure may be related to structural changes in the body of tadpoles such as gills that are related to physiological changes [60]. Moreover, Orme et al. [61] reported a reduced level of thyroxine in Sprague Dawley rats exposed to $\mathrm{ClO}_{2}$ during development and demonstrated anti-thyroid and neuro-behavioral effects during their development. Thyroid hormones play important roles in neuro-behavioral functioning during anuran development [32], however, studies regarding to thyrotoxicosis and neuro-behavioral performance are scarce.

\section{Cardiac rhythm}

The mean heart rate (heartbeats per minute) in 0.78 and $3.12 \mathrm{mg} \mathrm{L}^{-1} \mathrm{ClO}_{2}$ treated tadpoles significantly increased (84.61\% and $70.19 \% ; F=5.323, p<0.01)$ with respect to $\mathrm{CO}$ (Dunnett's test $p<0.01$ ) at $24 \mathrm{~h}$ (Fig. 3, Table S1). Heart rates were positively related $(r$ Spearman $=0.8 ; p<0.01)$ to some swimming parameters (total distance, mean speed) and GST activities.

Heart rate showed a significant $(F=7.25, p<0.01)$ increase in treated tadpoles exposed to $0.78,1.56$ and $3.12 \mathrm{mg} \mathrm{L}^{-1} \mathrm{ClO}_{2}$ concentrations after $96 \mathrm{~h}(75.88 \%, 84.93 \%$ and $69.64 \%$, respectively) respect to CO (Dunnett's test $p<$ 0.01 ; Fig. 3, Table S1). Heart rate showed a negative correlation with AChE $(r$ Spearman $=-1 ; p<0.01)$. Results of Spearman correlation between biological endpoints were summarized in Table S2 (supplementary material). The cardiac rhythm is recognized as effective biomarkers for amphibian's health in several ecotoxicological investigations $[32,39,41,62]$. In the present study, heart rate increased in
$\mathrm{ClO}_{2}$ treated tadpoles at 24 and after $96 \mathrm{~h}$. In contrast, reduction of heartbeats was reported in $\mathrm{ClO}_{2}$ treated larvae of $P$. interpunctella [47]. The relation among heart rhythm, oxidative stress, and GST activities were determined in tadpoles exposed to other chemicals such as pyriproxyfen, however, mechanisms involved in these relations remain unclear [32]. A study on pigeons (Columba livia) suggested that $\mathrm{ClO}_{2}$ may increase the risk of cardiac rhythm alteration due to an increase in plasma cholesterol levels and size of thrombocytes in blood vessels [63].

\section{Materials and methods}

\section{Chemical}

Chlorine dioxide was synthesized as described by Hey et al. [64] and Chhetri et al. [65]. Demineralized water (400 mL) was mixed with $25 \mathrm{~mL}$ of $4 \% \mathrm{HCl}$ and $25 \% \mathrm{NaClO}_{2}$. This mixture was diluted to $1000 \mathrm{~mL}$ in demineralized water after an overnight reaction. This procedure produced an approximately $1 \mathrm{~g} \mathrm{~L}^{-1}$ chlorine dioxide solution, which was used for three replicates of stock solutions of $100 \mathrm{mg}$ $\mathrm{L}^{-1} \mathrm{ClO}_{2}$. The stability of concentration of stock solutions was verified by chlorine dioxide Sensing Strip (Insta-TEST, LaMotte $($-USA) [66, 67] in lab conditions immediately after preparation and at every $24 \mathrm{~h}$ for three consecutive days. These observations were used for defining the renewal time of treatment solutions. The initial concentration $(0 \mathrm{~h})$ was reduced by $30 \%$ at $24 \mathrm{~h}$, and more than half at $48 \mathrm{~h}$, so it was decided to renew the solutions at every $48 \mathrm{~h}$.

\section{Organisms and experimental design}

Tadpoles (Gosner Stage 28-32) of the veined tree frog Trachycephalus typhonius were sampled from temporary small ponds from the Paraná River floodplain, Argentina ( $31^{\circ} 11^{\prime}$
Fig. 3 Heart rates (beats $\min ^{-1}$ ) of Trachycephalus typhonius tadpoles of control (CO) and chlorine dioxide $\left(\mathrm{ClO}_{2} \mathrm{mg} \mathrm{L}^{-1}\right)$ treatments at $24 \mathrm{~h}$ (left) and after $96 \mathrm{~h}$ (right) of exposure. $p<0.05(*)$ and $p<0.01(* *)$ indicates statistical differences with respect to $\mathrm{CO}$
$24 \mathrm{~h}$

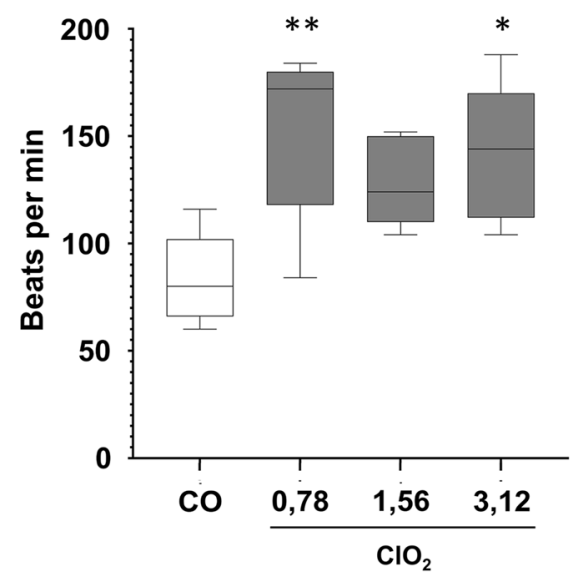

$96 \mathrm{~h}$

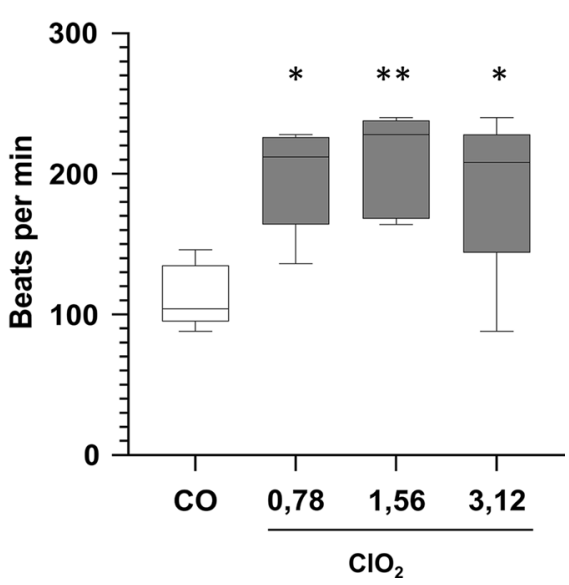


$\left.31^{\prime \prime} \mathrm{S}, 60^{\circ} 9^{\prime} 29^{\prime \prime} \mathrm{W}\right)$. Authorization for tadpole sampling was given by the Ministerio de Ambiente de la Provincia de Santa Fe (No 02101-0018518-1). Site of tadpole sampling was contamination-free, as determined in a previous research of our lab [68]. Tadpoles were transported immediately to laboratory in dechlorinated tap water (DTW) and acclimatized. Tadpoles' acclimation period was performed under controlled lab conditions of 12/12 h (light N100 Lx/ dark photoperiod cycles) at $24 \pm 2{ }^{\circ} \mathrm{C}$ for two days. Tadpole behavior such as eat and swim was checked daily.

The experiments followed regulations of ASIH [69]. Tadpoles were euthanized following the protocol of the Animal Euthanasia Guide proposed by the Institutional Animal Care and Use Committee and the Advisory Committee on Ethics and Safety in research of the Facultad de Bioquímica y Ciencias Biológicas of the Universidad Nacional del Litoral (No 388/06).

There is lack of environmental concentration data on aquatic ecosystems and doubts related to the fate of $\mathrm{ClO}_{2}$ on surface freshwater. For this reason, a first approximation to the toxicity of $\mathrm{ClO}_{2}$ on tadpoles was performed to determine the median lethal concentration $\left(\mathrm{LC}_{50}\right)$, similarly as previously performed for different contaminants [39]. A first bioassay was carried out by exposing three replicate solutions each containing 12 tadpoles. The nominal concentrations of $\mathrm{ClO}_{2}$ assayed were: $12.5,6.25,3.125,1.56$, and $0.78 \mathrm{mg} \mathrm{L}^{-1}$. Mortality was recorded at 24 and $48 \mathrm{~h}$ to estimate $\mathrm{LC}_{50}$, lowest-observed effect concentration (LOEC), and no-observed effect concentration (NOEC) values.

The sublethal effects (enzyme activities, swimming behavior, and heart rhythm as biomarkers) were evaluated in tadpoles of treatments with $\leq$ LOEC at 24 and after $96 \mathrm{~h}$ of exposure. These effects were analyzed in subsequent bioassays with the same lab conditions. The solutions were renewed at $48 \mathrm{~h}$ in the $96 \mathrm{~h}$ experiment.

\section{Biomarkers}

\section{Enzyme activities}

Tadpoles ( $n=7$ per treatment) were weighed $(\mathrm{g})$, and homogenized $(1: 10, \mathrm{w} / \mathrm{v})$ in ice-cold $25 \mathrm{mM}$ sucrose, 20 mMTris- $\mathrm{HCl}$ buffer ( $\mathrm{pH}^{1 / 4}$ 7.4) containing $1 \mathrm{mM}$ EDTA, using a polytron tissue grinder. The homogenates were centrifuged at $10,000 \mathrm{~g}$ for $15 \mathrm{~min}$ at $4 \pm 1{ }^{\circ} \mathrm{C}$, and stored at $-80{ }^{\circ} \mathrm{C}$ until measurements. Enzyme activities were quantified after considering total protein concentration by the Biuret method according to Kingsley [70]. AChE activity was determined colorimetrically following Ellman et al. [71] and expressed as nmol $\mathrm{min}^{-1} \mathrm{mg}^{-1}$ protein $\left(\mathrm{MEC}=13.6 \times 10^{3} \mathrm{M}^{-1} \mathrm{~cm}^{-1}\right.$ ). The reaction mixture consisted on $25 \mathrm{mM}$ Tris- $\mathrm{HCl}$ and contained $1 \mathrm{mM} \mathrm{CaCl} 2$ ( $\mathrm{pH}=7.6), 10 \mathrm{~mL} 20 \mu \mathrm{M}$ acetylthiocholineiodide, and $50 \mu \mathrm{L}$ 5,5-dithio-bis-(2-nitrobenzoic acid) $(3 \times 104 \mathrm{M}$, final concentration). The variation in optical density was measured in duplicate at $410 \mathrm{~nm}$ at $25{ }^{\circ} \mathrm{C}$ for $1 \mathrm{~min}$, using a Jenway 6405 UV-vis spectrophotometer. GST activity was measured spectrophotometrically according to Habig et al. [72] with modifications of Habdous et al. [73] for mammal serum GST activity. The measurement was performed with $340 \mathrm{~nm}$ in $100 \mathrm{mM} \mathrm{Na}$-phosphate buffer (pH 6.5), $20 \mu \mathrm{L}$ of $0.2 \mathrm{mM}$ 1-chloro-2,4-dinitrobenzene, $50 \mu \mathrm{L}$ of $5 \mathrm{mM}$ reduced glutathione, and the sample homogenates. GST activity was expressed as nmol $\mathrm{min}^{-1} \mathrm{mg}^{-1}$ protein (molar extinction coefficient, $\mathrm{MEC}=9.61 \times 10^{3} \mathrm{M}^{-1} \mathrm{~cm}^{-1}$ ).

\section{Swimming activity}

The swimming activity of individual tadpoles was recorded for one minute using a digital video camera (Motic ${ }, 10.0 \mathrm{M}$ pixel) that was mounted in a tripod and placed just above the petri dish. The petri dish was filled with $200 \mathrm{ml}$ of different treatment solutions, following procedures previously established in our lab [39, 74]. For each treatment, three tadpoles were evaluated independently.

Total distance moved $(\mathrm{cm})$, mean speed $\left(\mathrm{cm} \mathrm{seg}^{-1}\right)$, and global activity $\left(\mathrm{cm}^{2}\right)$ were evaluated on each tadpole. These behavior parameters were quantified and analyzed using video-tracking software Smart (3.0.02 PanLab Harvard Apparatus $\left.{ }^{\circledR}\right)$.

\section{Cardiac rhythm}

Cardiac rhythm was evaluated following the methodology described for other native amphibian species [32, 39]. The body of tadpoles ( $n=5$ per treatment) was located in a thin concave plate in ventral side up position. Continual transillumination on heart area (front quarter body) was applied bottom-up with a spot-led light (Luxeon Rebel 3 wat Led). Videos were recorded in completely immobile tadpoles with a remote-triggered portable USB Digital Microscope (Video capture resolution: $640 \times 480,30 \mathrm{fps}$ ) at lab conditions (constant $24^{\circ} \mathrm{C}$ ) during $15 \mathrm{~s}$.

The heart rate (HR; beats. $\mathrm{min}^{-1}$ ) was quantified from slow-speed digital videos by direct visual examination of maximum systole ventricle beating $[39,75]$. The number of beats measured in the recorded $15 \mathrm{~s}$ was multiplied by four to obtain the value of a complete one min $[76,77]$.

\section{Data analyzes}

The $\mathrm{LC}_{50}$ value and its respective $95 \%$ confidence limits (95\% CL) were calculated by the trimmed Spearman-Karber method [78]. Post-hoc comparison Dunnett's test was used to analyze means of mortality of LOEC and NOEC values [79]. The toxicity of this compound was estimated according 
to the hazard classification system for wastewater discharged into the aquatic environment because the effects of $\mathrm{ClO}_{2}$ were not previously studied for tadpoles [80]. The obtained $\mathrm{LC}_{50}$ value was transformed into Toxic Units (TU) following the criterion of Lajmanovich et al. [81]: $\mathrm{TU}=100 / \mathrm{LC}_{50}$. The values were classified into five classes: I (No acute toxicity $=\mathrm{TU}<0.4$; II (Slight acute toxicity) $=0.4<\mathrm{TU}<1$; III (Acute toxicity): $1<\mathrm{TU}<10$; IV (High acute toxicity): $10<\mathrm{TU}<100 ; \mathrm{V}$ (very high acute toxicity): TU $>100$.

The data of biomarkers were expressed as means \pm standard deviation (SD). Kolmogorov-Smirnov test and Levene test were used to confirm normality and homogeneity of variances, respectively. Differences in enzymatic activity of $\mathrm{CO}$ and $\mathrm{ClO}_{2}$ treated tadpoles were analyzed by oneway ANOVA and Dunnett's test for post-hoc comparisons. GraphPad InStad® software was used for statistical analyzes. In addition, Spearman correlations were used to evaluate correlation between all pairs of variables (biochemical, behavioral, and cardiac endpoints, shown in table S2 from Supplementary material) for each treatment at 24 and after $96 \mathrm{~h}$ exposure. Values were considered significant at $p<$ 0.05 . No significant differences were found among replicates $(p>0.05)$, so, replicates from each treatment were pooled.

\section{Conclusion}

The present study determined the toxicity of $\mathrm{ClO}_{2}$ in amphibian tadpoles for first time worldwide. These data would be included in the maximum concentration criterion of chlorine compound toxicity assessment that has only been determined for freshwater fish and invertebrates. Our findings indicate a high risk of $\mathrm{ClO}_{2}$ exposure to anuran tadpoles that present alterations of AChE and GST enzymes, swimming behavior, and cardiac rhythm. The relevance of our study resides in the fact that this compound that extensively and continuously input to water become a threat for aquatic organisms and aquatic ecosystems functions and services, many of which are essential to human well—being.

Supplementary Information The online version contains supplementary material available at https://doi.org/10.1007/s13530-021-00116-3.

Acknowledgements We acknowledge Boccioni L.S. for supplying the chemical compounds for test solutions preparation and Lajmanovich R.F. for providing information regarding to the erroneous human $\mathrm{ClO}_{2}$ use as "miracle mineral solution". We also thanks to ANPCyT FONCyT and UNL for providying subsidies (PICT 2017 N 1069-RCL; CAI+D 2020-PMP). Finally, we acknowledge reviewers for their comments and suggestions.

Author contributions Conceptualization: RL and PP; Methodology: PP, ACB, CM, AA and CC; Formal analysis and investigation: PP, $\mathrm{ACB}$; Writing - original draft preparation and Writing-review and editing: PP, ACB and RL.
Funding This study was supported in part by National Agency for Promotion of Science and Technology, Argentine (ANPCyT FONCyT PICT, No. 1069), and Course of Action for Research and Science Promotion, Argentine (CAI D-UNL, PIC No. 100004 LI).

Availability of data and material Data presented in this study are available on request from the corresponding author.

\section{Declarations}

Conflict of interest Paola M. Peltzer, Ana P. Cuzziol Boccioni, Andrés M. Attademo, Candela S. Martinuzzi, Carlina L. Colussi, and Rafael C. Lajmanovich declare that we have no conflict of interest.

Ethics approval Animals were treated according the Institutional Committee for the Care and Use of Animals (IACUC), and approval was obtained from the bioethics committee of the FBCB-UNL (Res. No. 388/06)

\section{References}

1. Vertova A, Miani A, Lesma G, Rondinini S, Minguzzi A, Falciola L, Ortenzi MA (2019) Chlorine dioxide degradation issues on metal and plastic water pipes tested in parallel in a semi-closed system. Int J Environ Res Public Health 16(22):4582. https://doi. org/10.3390/ijerph16224582

2. Gordon G, Rosenblatt AA (2005) Chlorine dioxide: the current state of the art. Ozone Sci Eng 27(3):203-207

3. Chatuev BM, Peterson JW (2010) Analysis of the sporicidal activity of chlorine dioxide disinfectant against Bacillus anthracis (Sterne strain). J Hosp Infect 74(2):178-183. https://doi.org/10. 1016/j.jhin.2009.09.017

4. Ogata N, Shibata T (2009) Effect of chlorine dioxide gas of extremely low concentration on absenteeism of schoolchildren. Int J Med Med Sci 1(7):288-289. https://doi.org/10.5897/IJMMS. 9000077

5. Kály-Kullai K, Wittmann M, Noszticzius Z, Rosivall L (2020) Can chlorine dioxide prevent the spreading of coronavirus or other viral infections? Med Hypotheses Physiol Int 107(1):1-11. https:// doi.org/10.1556/2060.2020.00015

6. Wang J, Shen D, Ye X, Yan Y, Zhang W et al (2020) Disinfection technology of hospital wastes and wastewater: suggestions for disinfection strategy during coronavirus Disease 2019 (COVID-19) pandemic in China. Environ Pollut 262:114665. https://doi.org/ 10.1016/j.envpol.2020.114665

7. Trigo MS, Kurmanaev A, Cabrera JML (2020) Coronavirus en América Latina: algunas autoridades respaldan tratamientos cuestionables. NY Times. Available online at: https://www.nytimes. com/es/2020/07/23/espanol/america-latina/bolivia-cloro-coron avirus-ivermectina.html. Accessed 11 Aug 2021

8. Bendezu-Quispe G, Rodríguez-Zúñiga MJM, Roman YM, MoriLlontop LM, Peralta V, Fiestas F (2020) Agentes potencialmente terapéuticos contra el SARS-CoV-2: revisión rápida de la evidencia. Rev Peru Med Exp Salud Pública 37(2):320-326. https://doi. org/10.17843/rpmesp.2020.372.5409

9. Burela A, Hernández-Vásquez A, Comandé D, Peralta V, Fiestas F (2021) Dióxido de cloro y derivados del cloro para prevenir o tratar la COVID-19: revisión sistemática. Rev Peru Med Exp Salud Publica 37:605-610. https://doi.org/10.17843/rpmesp.2020. 374.6330

10. Mostajo-Radji MA (2021) Pseudoscience in the times of crisis: how and why chlorine dioxide consumption became popular in 
Latin America during the COVID-19 pandemic. Front Polit Sci 3:25. https://doi.org/10.3389/fpos.2021.621370

11. García-Ávila F, Valdiviezo-Gonzales L, Cadme-Galabay M, Gutiérrez-Ortega H, Altamirano-Cárdenas L, Zhindón-Arévalo C, Flores del Pino L (2020) Considerations on water quality and the use of chlorine in times of SARS-CoV-2 (COVID-19) pandemic in the community. Case Stud CSCEE 2:100049. https://doi.org/ 10.1016/j.cscee.2020.100049

12. Quevedo R, Bastías JM, Espinoza T, Ronceros B, Balic I, Muñoz $\mathrm{O}$ (2020) Inactivation of Coronaviruses in food industry: the use of inorganic and organic disinfectants, ozone, and UV radiation. Scientia Agropecuaria 11(2):257-266

13. Kitajima M, Ahmed W, Bibby K, Carducci A, Gerba CP, Hamilton KA, Haramoto E, Rose JB (2020) SARS-CoV-2 in wastewater: state of the knowledge and research needs. Sci Total Environ 739:139076. https://doi.org/10.1016/j.scitotenv.2020.139076

14. Environmental Assessment for Food Contact Notification No. 1804. Available at https://www.fda.gov/food/environmentaldecisions/environmental-decision-memo-food-contact-notificati on-no-1804

15. Toxicological profile for chlorine dioxide and chlorite. Available at: https://www.atsdr.cdc.gov/toxprofiles/tp160.pdf

16. Dewey HM, Jones JM, Keating MR, Budhathoki-Uprety J (2021) Increased use of disinfectants during the COVID-19 pandemic and its potential impacts on health and safety. ACS Chem Health Saf

17. Chu W, Fang C, Deng Y, Xu Z (2020) Intensified disinfection amid COVID-19 pandemic poses potential risks to water quality and safety. Environ Sci Technol 55(7):4084-4086

18. Junli HLW, Nenqi R, Li LX, Fun SR, Guanle Y (1997) Disinfection effect of chlorine dioxide on viruses, algae, and animal planktons in water. Wat Res 31:455-460. https://doi.org/10.1016/ S0043-1354(96)00276-X

19. Wigginton KR, Pecson BM, Sigstam T, Bosshard F, Kohn T (2012) Virus inactivation mechanisms: impact of disinfectants on virus function and structural integrity. Environ Sci Technol 46(21):12069-12078. https://doi.org/10.1021/es3029473

20. Kingsley DH, Pérez-Pérez RE, Niemira BA, Fan X (2018) Evaluation of gaseous chlorine dioxide for the inactivation of Tulane virus on blueberries. Int J Food Microbiol 273:28-32. https://doi. org/10.1016/j.jifoodmicro.2018.01.024

21. Hose JE, Di Fiore D, Parker HS, Sciarrotta T (1989) Toxicity of chlorine dioxide to early life stages of marine organisms. Bull Environ Contam Toxicol 42(3):315-319. https://doi.org/10.1007/ BF01699954

22. Svecevicius G, Syvokiene J, Stasiŭnaite P, Mickeniene L (2005) Acute and chronic toxicity of chlorine dioxide $(\mathrm{ClO} 2)$ and chlorite (ClO2-) to rainbow trout (Oncorhynchus mykiss). Environ Sci Pollut Res Int 5:302-305. https://doi.org/10.1065/espr2005.04.248

23. Sun XB, Cui FY, Guo ZH (2007) Toxicity and influencing factors of chlorine dioxide to chironomid larvae. Huan Jing KeXue 11:2569-2573

24. Kos J, Brmež M, Markić M, Sipos L (2019) The mortality of nematodes in drinking water in the presence of ozone, chlorine dioxide, and chlorine. Ozone Sci Eng 42:120-127

25. Burton DT, Fisher DJ (2001) Chlorine dioxide: the state of science, regulatory, environmental issues, and case histories. In: Proceedings of the 4th international symposium, Las Vegas, NV

26. Blaustein AR, Bancroft BA (2007) Amphibian population declines: evolutionary considerations. Bioscience 57(5):437-444. https://doi.org/10.1641/B570517

27. Hayes TB, Falso P, Gallipeau S, Stice M (2010) The cause of global amphibian declines: a developmental endocrinologist's perspective. J Exp Biol Mar 213(6):921-933. https://doi.org/10. 1242/jeb.040865

28. Blaustein AR, Han BA, Relyea RA, Johnson PT, Buck JC, Gervasi SS, Kats LB (2011) The complexity of amphibian population declines: understanding the role of cofactors in driving amphibian losses. Ann N Y Acad Sci 1223:108-119. https://doi.org/10. 1111/j.1749-6632.2010.05909.x

29. Egea-Serrano A, Relyea RA, Tejedo M, Torralva M (2012) Understanding of the impact of chemicals on amphibians: a meta-analytic review. Ecol evol 2(7):1382-1397. https://doi.org/10.1002/ ece 3.249

30. Connon RE, Geist J, Werner I (2012) Effect-based tools for monitoring and predicting the ecotoxicological effects of chemicals in the aquatic environment. Sensors 12(9):12741-12771. https://doi. org/10.3390/s120912741

31. Brodeur JC, Poliserpi MB, D’Andrea MF, Sánchez M (2014) Synergy between glyphosate- and cypermethrin-based pesticides during acute exposures in tadpoles of the common South American Toad Rhinella arenarum. Chemosphere 112:70-76. https://doi. org/10.1016/j.chemosphere.2014.02.065

32. Lajmanovich RC, Peltzer PM, Martinuzzi CS, Attademo AM, Bassó A, Colussi CL (2019) Insecticide pyriproxyfen (Dragón®) damage biotransformation, thyroid hormones, heart rate, and swimming performance of Odontophrynusamericanus tadpoles. Chemosphere 220:714-722. https://doi.org/10.1016/j.chemo sphere.2018.12.181

33. Bahl MF, Brodeur JC, Costa CS, D'Andrea MF, Sansiñena JA, Marino DJ, Natale GS (2021) Lethal and sublethal effects of the natural and healthy spinosad-based formulation Tracer $^{\mathrm{TM}}$ on tadpoles of two neotropical species. Environ Sci Pollut Res 28(11):13524-13535. https://doi.org/10.1007/ s11356-020-09808-8

34. Peltzer PM, Junges CM, Attademo AM, Bassó A, Grenón P, Lajmanovich RC (2013) Cholinesterase activities and behavioral changes in Hypsiboas pulchellus (Anura: Hylidae) tadpoles exposed to glufosinate ammonium herbicide. Ecotoxicology 22(7):1165-1173. https://doi.org/10.1007/s10646-013-1103-8

35. Nunes B (2011) The use of cholinesterases in ecotoxicology. In: Whitacre DM (ed) Reviews of environmental contamination and toxicology. Springer, New York, pp 29-60

36. Walker CH, Hopkin SP, Sibly RM, Peakall DB (2001) Principles of ecotoxicology, 2nd edn. Taylor and Francis, New York

37. Denoël M, D'Hooghe B, Ficetola GF, Brasseur C, De Pauw E, Thomé JP, Kestemont P (2012) Using sets of behavioral biomarkers to assess short-term effects of pesticide: a study case with endosulfan on frog tadpoles. Ecotoxicology 21:1240-1250

38. Prokić MD, Borković-Mitić SS, Krizmanić II, Mutić JJ, Gavrić JP, Despotović SG, Saičić ZS (2017) Oxidative stress parameters in two Pelophylax esculentus complex frogs during pre-and posthibernation: arousal vs heavy metals. Comp Biochem Physiol Part C Toxicol Pharmacol 202:19-25

39. Peltzer PM, Lajmanovich RC, Martinuzzi C, Attademo AM, Curi LM, Sandoval MT (2019) Biotoxicity of diclofenac on two larval amphibians: Assessment of development, growth, cardiac function and rhythm, behavior and antioxidant system. Sci Total Environ 683:624-637. https://doi.org/10.1016/j.scitotenv.2019.05.275

40. Fernández LP, Brasca R, Attademo AM, Peltzer PM, Lajmanovich RC, Culzoni MJ (2020) Bioaccumulation and glutathione S-transferase activity on Rhinellaarenarum tadpoles after short-term exposure to antiretrovirals. Chemosphere 246:125830. https:// doi.org/10.1016/j.chemosphere.2020.125830

41. Costa MJ, Monteiro DA, Oliveira-Neto AL, Rantin FT, Kalinin AL (2008) Oxidative stress biomarkers and heart function in bullfrog tadpoles exposed to Roundup Original. Ecotoxicology 17(3):153-163. https://doi.org/10.1007/s10646-007-0178-5

42. Perrichon P, Pasparakis C, Mager EM, Stieglitz JD, Benetti DD, Grosell M, Burggren WW (2017) Morphology and cardiac physiology are differentially affected by temperature in developing larvae of the marine fish mahi-mahi (Coryphaena hippurus). Biology open 6(6):800-809 
43. Denoël M, Libon S, Kestemont P, Brasseur C, Focant JF, De Pauw E (2013) Effects of a sublethal pesticide exposure on locomotor behavior: a video-tracking analysis inlarval amphibians. Chemosphere 90:945e951

44. Couri D, Abdel-Rahman MS, Bull RJ (1982) Toxicological effects of chlorine dioxide, chlorite and chlorate. Envir Health Persp 46:13

45. Yonkos LT, Fisher DJ, Wright DA, Kane AS (2000) Pathology of fathead minnows (Pimephales promelas) exposed to chlorine dioxide and chlorite. Mar Environ Res 50(1-5):267-271. https:// doi.org/10.1016/S0141-1136(00)00048-9

46. López-Galindo C, Vargas-Chacoff L, Nebot E, Casanueva JF, Rubio D, Solé M, Mancera JM (2010) Biomarker responses in Soleasenegalensis exposed to sodium hypochlorite used as antifouling. Chemosphere 78(7):885-893. https://doi.org/10.1016/j. chemosphere.2009.11.022

47. Kim M, Kwon H, Kim W, Kim Y (2016) Enhanced Acetylcholinesterase activity of the Indianmeal Moth, Plodia interpunctella, under chlorine dioxide treatment and altered negative phototaxis behavior. Kor J Appl Entomol 55(1):27-33

48. Matsushita T, Fujita Y, Omori K, Huang Y, Matsui Y, Shirasaki N (2020) Effect of chlorination on anti-acetylcholinesterase activity of organophosphorus insecticide solutions and contributions of the parent insecticides and their oxons to the activity. Chemosphere 261:127743

49. Carvalho CS, Utsunomiya HS, Pasquoto T, Costa MJ, Fernandes MN (2017) Cholinesterase activity as potential biomarkers: Characterization in bullfrog tadpole's brain after exposure to metals. In: XVII safety, health and environment world congress, Vila Real, Portugal, pp 86-88

50. Barillet S, Adam-Guillermin C, Palluel O, Porcher JM, Devaux A (2011) Uranium bioaccumulation and biological disorders induced in zebrafish (Danio rerio) after a depleted uranium waterborne exposure. Environ Pollut 159(2):495-502

51. Pozzetti L, Broccoli M, Potenza G, Canestro D, Affatato A, Sapone A, Antelli A, D’Amico E, Vangelisti S, Cantelli-Forti G, Paolini M, Ferrara G, Elia AC, Do“rr AJM, Taticchi MI, Mantilacci L, Natali M, (2003) Tecnicheenzimatiche per valutare la tossicita`di acquepotabilizzate. Acqua Aria 4:64-68

52. Elia AC, Anastasi V, Dörr AJM (2006) Hepatic antioxidant enzymes and total glutathione of Cyprinus carpio exposed to three disinfectants, chlorine dioxide, sodium hypochlorite and peracetic acid, for superficial water potabilization. Chemosphere 64(10): 1633-1641

53. Ison A, Odeh IN, Margerum DW (2006) Kinetics and mechanisms of chlorine dioxide and chlorite oxidations of cysteine and glutathione. Inorg Chem 45(21):8768-8775

54. Bonansea RI, Wunderlin DA, Amé MV (2016) Behavioral swimming effects and acetylcholinesterase activity changes in Jenynsia multidentata exposed to chlorpyrifos and cypermethrin individually and in mixtures. Ecotox Environ Safe 129:311-319

55. Ren Q, Zhao R, Wang C, Li S, Zhang T, Ren Z, Wang X (2017) The role of AChE in swimming behavior of Daphnia magna: correlation analysis of both parameters affected by deltamethrin and methomyl exposure. J Toxicol. https://doi.org/10.1155/ 2017/3265727

56. Ballesteros ML, Durando PE, Nores ML, Díaz MP, Bistoni MA, Wunderlin DA (2009) Endosulfan induces changes in spontaneous swimming activity and acetylcholinesterase activity of Jenynsia multidentata (Anablepidae, Cyprinodontiformes). Environ Poll 157(5):1573-1580

57. Pan H, Zhang X, Ren B, Yang H, Ren Z, Wang W (2017) Toxic assessment of cadmium based on online swimming behavior and the continuous AChE activity in the gill of zebrafish (Danio rerio). Water Air Soil Pollut 228(9):1-9
58. Kaufer D, Friedman A, Seidman S, Soreq H (1998) Acute stress facilitates long-lasting changes in cholinergic gene expression. Nature 393(6683):373-377

59. Choi E, Alsop D, Wilson JY (2018) The effects of chronic acetaminophen exposure on the kidney, gill and liver in rainbow trout (Oncorhynchus mykiss). Aquat Toxicol 198:20-29

60. Lajmanovich RC, Izaguirre MF, Casco VH (1998) Paraquat tolerance and alteration of internal gill structure of Scinax nasica tadpoles (Anura: Hylidae). Arch Environ Contam Toxicol 34:364-369

61. Orme J, Taylor DH, Laurie RD, Bull RJ (1985) Effects of chlorine dioxide on thyroid function in neonatal rats. J Toxicol Environ Health A Curr Issues 15(2):315-322

62. Dal-Medico SE, Rissoli RZ, Gamero FU, Victório JA, Salla RF, Abdalla FC, Costa MJ (2014) Negative impact of a cadmium concentration considered environmentally safe in Brazil on the cardiac performance of bullfrog tadpoles. Ecotoxicol Environ Safe 104:168-174

63. Revis NW, McCauley P, Bull R, Holdsworth G (1986) Relationship of drinking water disinfectants to plasma cholesterol and thyroid hormone levels in experimental studies. PNAS 83(5):1485-1489

64. Hey G, Ledin A, Jansen JLC, Andersen HR (2012) Removal of pharmaceuticals in biologically treated wastewater by chlorine dioxide or peracetic acid. Environ Technol 33:1041-1047. https:// doi.org/10.1080/09593330.2011.606282

65. Chhetri RK, Baun A, Andersen HR (2019) Acute toxicity and risk evaluation of the CSO disinfectants performic acid, peracetic acid, chlorine dioxide and their by-products hydrogen peroxide and chlorite. Sci Total Environ 677:1-8. https://doi.org/10.1016/j. scitotenv.2019.04.350

66. Lee YB, Kim WS (2020) $\mathrm{ClO} 2$ Dipping treatment inhibits gray mold on cut rose flowers during storage. Hort J UTD 138

67. Han GD, Na J, Chun YS, Kumar S, Kim W, Kim Y (2017) Chlorine dioxide enhances lipid peroxidation through inhibiting calcium-independent cellular PLA2 in larvae of the Indianmeal moth, Plodia interpunctella. Pestic Biochem Physiol 143:48-56

68. Lajmanovich RC, Attademo AM, Lener G, Cuzziol Boccioni AP, Peltzer PM, Martinuzzi CS, Repetti MR (2021) Glyphosate and glufosinate ammonium, herbicides commonly used on genetically modified crops, and their interaction with microplastics: Ecotoxicity in anuran tadpoles. STOTEN 150177

69. ASIH (2004) Guidelines for use of live amphibians and reptiles in field and laboratory research. Lawrence, Kansas: Herpetological Animal Care and Use Committee (HACC) of the American Society of Ichthyologists and Herpetologists

70. Kingsley GR (1942) The direct biuret method for the determination of serum proteins as applied to photoelectric and visual colorimetry. J Lab Clin Med 27:840-845

71. Ellman GL, Courtney KD, JrV A, Featherstone RM (1961) A new and rapid colorimetric determination of acetylcholinesterase activity. Biochem Pharmacol 7(2):88-95

72. Habig WH, Pabst MJ, Jakoby WB (1974) Glutathione Stransferase: the first step in mercapturic acid formation. J Biol Chem 249:7130-7139

73. Habdous M, Vincent-Viry M, Visvikis S, Siest G (2002) Rapid spectrophotometric method for serum glutathione $\mathrm{S}$-transferases activity. Clin Chim Acta 326(1-2):131-142

74. Junges CM, Maglianese MI, Lajmanovich RC, Peltzer PM, Attademo AM (2017) Acute toxicity and etho-toxicity of three insecticides used for mosquito control on amphibian tadpoles. Water Air Soil Pollut 228(4):143

75. Chan PK, Lin CC, Cheng SH (2009) Non invasive technique for measurement of heartbeat regularity in zebrafish (Danio rerio) embryos. BMC Biotechnol 9(1):11. https://doi.org/10.1186/ 1472-6750-9-11 
76. Kang R, Jeong JS, Yoo JC, Lee JH, Choi SJ, Gwak MS, Ko JS (2018) Effective dose of intravenous dexmedetomidine to prolong the analgesic duration of interscalene brachial plexus block: a single-center, prospective, double-blind, randomized controlled trial. Reg Anesth Pain Med 43(5):488-495

77. Hoage T, Ding Y, Xu X (2012) Quantifying cardiac functions in embryonic and adult zebrafish. In: Cardiovascular development, Humana Press, Totowa, New Jersey, pp 11-20

78. Hamilton MA, Russo RC, Thurston RV (1977) Trimmed spearman-karber method for estimating median lethal concentrations in toxicity bioassays. Environ Sci Technol 11:714-719

79. US EPA (U.S. Environmental Protection Agency). Short-term methods for estimating the chronic toxicity of effluents and receiving waters to fresh water organisms; Report No. EPA/600/ 4-89/001. Environmental Protection Agency: Cincinnati, OH, 1989

80. Persoone G, Marsalek B, Blinova I, Torokne A, Zarina D, Manusadzianas L, Nalecz-Jawecki G, Tofan L, Stepanova N, Tothova L, Kolar B (2003) A practical and user-friendly toxicity classification system with microbiotests for natural waters and wastewaters. Environ Toxicol 18(6):395-402. https://doi.org/10.1002/tox. 10141

81. Lajmanovich RC, Peltzer PM, Martinuzzi CS, Attademo AM, Colussi CL, Basso A (2018) Acute toxicity of colloidal silicon dioxide nanoparticles on amphibian larvae: emerging environmental concern. Int J Environ Sci 12(3):269-278 